\title{
Casuarina cunninghamiana Miq. (River sheoak) in Florida and Its Potential as a Windbreak Plant for Citrus Groves ${ }^{1}$
}

\author{
William S. Castle, Kenneth A. Langeland, and Donald L. Rockwood ${ }^{2}$
}

\section{Introduction}

Canker and Huanglongbing (HLB; a.k.a. greening) bacterial diseases are present in Florida and damaging the citrus industry. Details about the biology, management and impacts of these diseases are available in other EDIS documents.

Canker is spread by wind-blown rain; thus, one management strategy for protecting trees is to establish living windbreaks that moderate wind. They also provide the added benefit of improving packouts of fresh fruit because of less wind scar. The use of windbreaks is a well established tool for canker management throughout the world. A proven plant species for this purpose is Casuarina cunninghamiana, judging from its common to almost exclusive use in the fresh fruit citrus industries of Argentina, South Africa, and Australia. Fast growth, ease of establishment, cold hardiness, ability to produce some of its own nitrogen, and life-long foliation from top to bottom with good branching are attributes of this species that favor its use as windbreak. Those same attributes would be equally useful in Florida citrus grove situations for the management of canker, but it is not as clear whether windbreaks provide any advantages for HLB management, since a small insect [Diaphorina citri (psyllid)], rather than windblown rain, as in citrus canker, is the vector transmitting the casual bacterium of HLB. Strategies for HLB are often focused on chemical management of the insect vector.

This review was undertaken to compile pertinent information and provide an historical perspective for environmentalists, biologists, scientists, and other interested parties regarding the Casuarina species in Florida, which are presently classified as invasive and illegal to possess or propagate.

\section{Botanical Classification and Traits of Casuarina Species}

Casuarina is one of four genera in the Casuarinaceae family (Wilson and Johnson, 1989). The species in this genus are angiosperms with dicotyledonous seeds. They are evergreen trees with needle-like foliage and woody seed-bearing cones. They occur naturally in eastern and northeastern Australia and elsewhere in Southeast Asia, including many of the intervening islands of the Pacific Ocean such as those of Melanesia and Polynesia. The various species are vigorous growers and adapted to a broad range of site conditions (Rockwood et al., 1990). They grow well in many soil types, areas of naturally low fertility, and in disturbed soils. They fix nitrogen as a result of actinorhizal root nodules that form with a bacterial symbiont in the genus Frankia (El-Lakany, 1996).

1. This document is HS1139, one of a series of the Horticultural Sciences Department, Florida Cooperative Extension Service, Institute of Food and Agricultural Sciences, University of Florida. Original publication date May 2008. Revised October 2012. Visit the EDIS website at http://edis.ifas.ufl.edu.

2. William S. Castle, emeritus professor, Citrus REC, Lake Alfred, Florida, Horticultural Sciences Department; Kenneth A. Langeland, emeritus professor, Department of Agronomy, Center for Aquatic and Invasive Plants; and Donald L. Rockwood, professor, School of Forest Resources and Conservation; Cooperative Extension Service, Institute of Food and Agricultural Sciences, University of Florida, Gainesville, FL 32611. 
Three species of Casuarina occur in Florida: C. cunninghamiana, C. equisetifolia, and C. glauca (Woodall and Geary, 1985). They are easily recognized by their distinctive needle-like foliage leading to the common misnomer, "Australian Pine." The term "needle," while botanically incorrect, is convenient and is used in this document. These "needles" are actually formed from overlapping whorls of leaves fused into a cylinder that surrounds true stem tissue. Each leaf terminates with a pointed, tooth-like structure giving the "needle" the appearance of nodes with whorls of very small leaves (teeth) at each node. Thus, the needle is termed "jointed" and the length of the region between nodes is useful in identifying each species. These "nodes" are easily seen with the naked eye. The needles in crosssection are circular with ridges and furrows. The features of the cross-section are diagnostic. Some needles undergo secondary growth and essentially become stems, while others do not and they eventually abscise. The latter needles are termed "branchlets."

The following descriptions are of the three species as they occur in Florida (see cited literature for details) and emphasize diagnostic features useful in distinguishing the species. A guide to field identification is available on EDIS.

\section{C. cunninghamiana Miq. (AgroForestryTree Database)} flowers basically in the same manner as the other species, except it is dioecious (male and female flowers on separate plants; see also Boland et al., 1996). Leaf-teeth typically number 7 to 10 , are sharply pointed, and, because the tips are usually grayish-brown, the whorl of teeth has a brown ring about halfway between the base of the teeth and their tips (Fig. 1). The cones of the few female trees found in Florida are smaller in size and fewer in number than those generally observed on C. equisetifolia trees (Fig. 1).

The trees are fast-growing and tall, reaching heights of 100 feet or more at maturity (Fig. 1), but they are the smallest and least vigorous among the three species in Florida according to Woodall and Geary (1985). The branches and needles are droopy, giving the tree a soft appearance. The bark on mature trees is fissured, somewhat blocky, and useful in species identification (Fig. 1). A slight tendency to form root suckers has been reported for plants growing elsewhere, but they are apparently uncommon in Florida.

C. equisetifolia L. (AgroForestryTree Database) is predominantly a monoecious (male and female flowers occur on the same plant) species. Studies of seedling populations of this species have shown that dioecious plants can appear as well as non-flowering plants (Yashoda et al., 2004). Female flowers are borne along the stems and male flowers at the

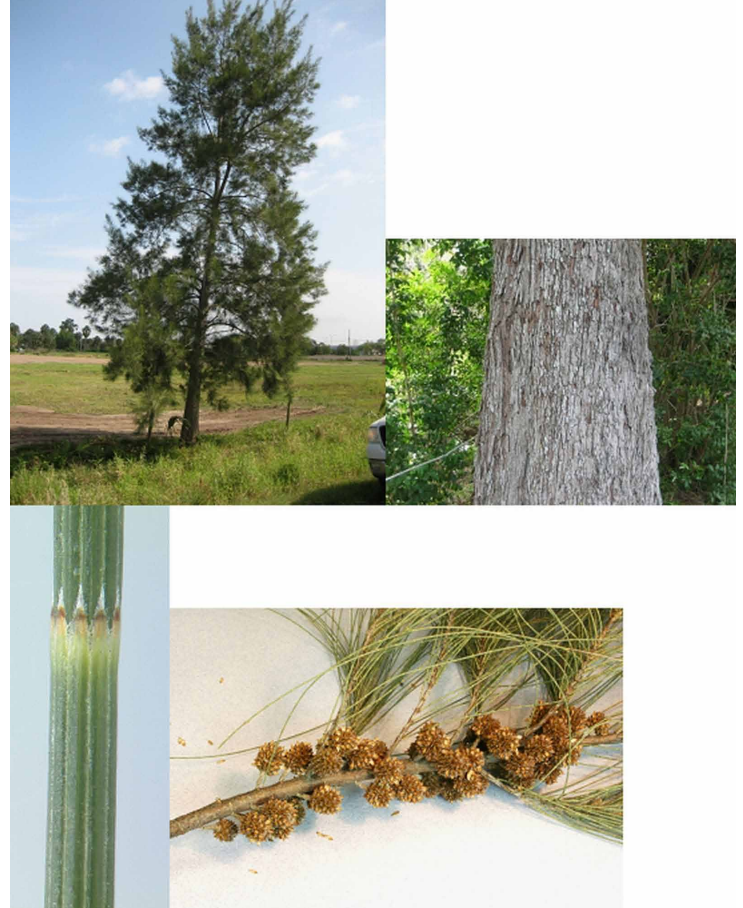

Figure 1. Mature Florida tree, bark, cones and needle of Casuarina cunninghamiana.

ends of needles. The plants may flower several times in the warmer months of the year beginning in the spring. Pollination is by wind. Cones are relatively abundant, slightly longer than they are wide, and may be slightly pubescent or hairy (Fig. 2). When they open, very small, single-winged seeds are ejected. Leaf-teeth number 6 to 8 , but mostly 7 (Fig. 2). The teeth lack the brown band present in the other two species. They are usually whitish in color and occasionally have a brown tip. The furrows formed between adjacent leaves along the stem between nodes are usually filled with white hairs.

Plants of this species do not produce root suckers, and they coppice (produce new shoots from tree stumps) weakly. Mature trees have an open, irregular crown (Fig. 2). Their bark is thin and lacks well defined fissures. When bark sections weather and are shed from growth, the color underneath can range from orange to bright red (Fig. 2). Individual trees may reach mature heights of 100 feet or taller. Reports vary on when trees may begin flowering and range from 1 to 5 years. Tree growth rates are reportedly from 3 (uncultivated) to 10 feet (cultivated)/year.

\section{C. glauca Sieber ex Sprengle (AgroForestryTree Database)} is dioecious. The leaf-teeth number is the largest of the three species and ranges from 10-14 (Fig. 3). Also distinctive is the brown band that occurs at the base of the teeth where they join together. A question remains as to whether this species forms cones in Florida. 


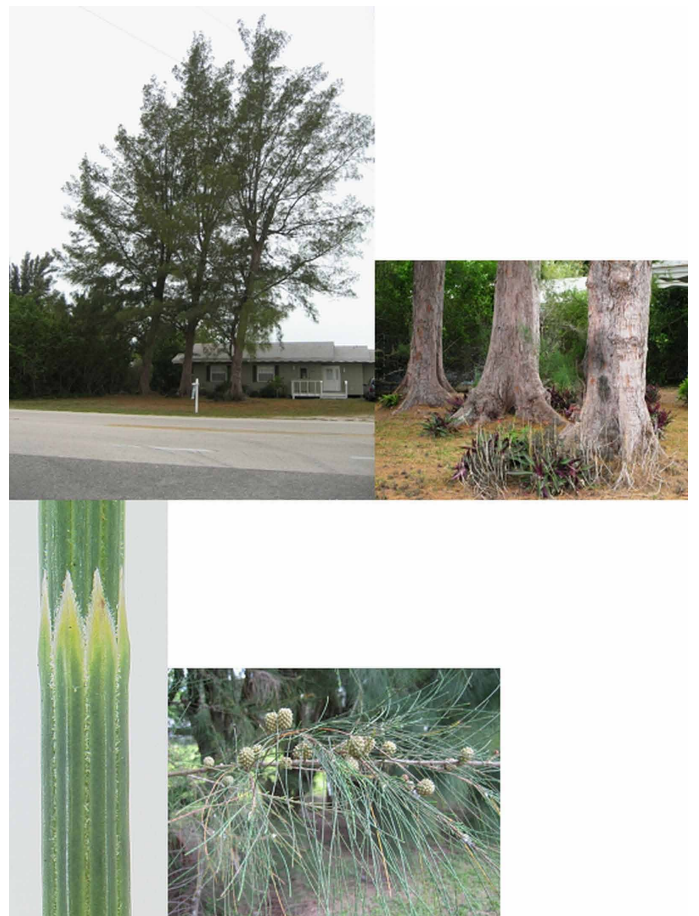

Figure 2. Mature Florida tree, bark, needles and cones of Casuarina equisetifolia.

The trees are moderately tall, perhaps 60 feet at maturity, and rarely occur in the environment as individual trees because they easily spread by root suckers, and their stumps coppice readily (Fig. 3). The trees have a tendency to branch strongly in the upper canopy, leading to a crown profile that is largely upright, smooth, and relatively narrow. The tree is actually quite attractive because of its dark green foliage contrasted with a gray bark (Fig. 3) and a generally dense canopy. Tree appearance is similar to C. cunninghamiana in that the branches and branchlets are droopy, and give the tree a soft look, but the branches and needles are visibly longer in C. glauca. Stands consisting of mature trees and root suckers give the appearance of a small individual plant community.

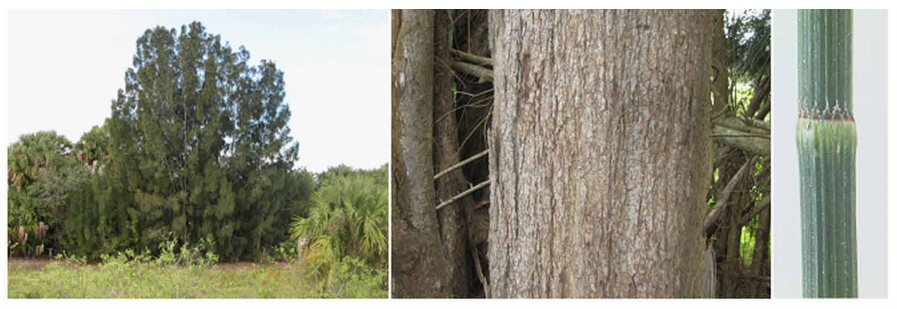

Figure 3. Mature Florida tree, bark and needle of Casuarina glauca.

\section{Propagation}

Seeds are the preferred method of propagation because they are abundant and easy to handle, but germination percentages can vary from 30 to $70 \%$ depending on such factors as species, season of harvest and the collection site within the tree canopy (El-Lakany, 1996; El-Lakany et al., 1989; Olsen et al., undated). Poor germination may result from high proportions of shriveled, empty, and insectdamaged seeds that can be separated from "good" seeds by a flotation technique that can improve the germination percentage (Sivakumar et al., 2007). Seeds germinate in 2 to 3 weeks. Some care is required to prevent diseases caused by overwatering and damage from predators like ants. The dioecious Casuarina species tend to produce seedling populations with 1:1 ratios of male to female plants, but the ratio may vary and individual plants may be sexually unstable (Boland et al., 1996; Yasodha et al., 2004).

C. cunninghamiana seeds are plentiful and handled as with C. equisetifolia. It is recommended to inoculate the roots of the three species with cultures of Frankia (AgroForestryTree Database).

C. equisetifolia seeds are best germinated at ca. $30^{\circ} \mathrm{C}$ and no pre-sowing treatment is required. Plants suitable for outplanting, i.e., 12 to 24 inches tall, can be achieved within a few months (AgroForestryTree Database).

C. glauca cones apparently produce fewer seeds than those of the other species with seed germination rates of only ca. $60 \%$. Germination is best at temperatures between 20 and $25^{\circ} \mathrm{C}$ (AgroForestryTree Database).

Propagation by asexual means, primarily cuttings, is also practiced commercially with varying results depending on the type of cutting, the species, and other factors (Goh, et al., 1995; Karoshi et al., 2000; Lindquist and Torrey, 1984). The primary interests in this method are to preserve by clonal propagation genetic improvements achieved by research (Boland et al., 1996) and to propagate superior trees for commercial plantations (Lal et al., 1996). Micropropagation by tissue culture techniques has also been evaluated and some preliminary success achieved (Duhoux et al., 1996; Parthiban et al., 1996).

Reports indicating that the Casuarinas can be propagated as cuttings often lack any information about the specific conditions or degree of success. It is usually recommended that juvenile stem cuttings about 1 to $2 \mathrm{~mm}$ in diameter be selected, treated with root-inducing hormones like IBA (indolebutyric acid), IAA (indoleacetic acid) or NAA (naphthalyacetic acid), and rooted in heated mist beds (Kha, 1996).

In one formal study, cuttings of C. equisetifolia and $C$. cunninghamiana were taken from 6 -year-old seedlings 
and given 3-hour basal soaks of commercial IAA or IBA compounds or prepared solutions of them or NAA before rooting in sand beds or water cultures (Lundquist and Torrey, 1984). Softwood cuttings rooted better than hardwood cuttings. Across the various treatments and the two species, only ca. $50 \%$ of the cuttings rooted after 35 days. Misting the sand beds was discontinued because of persistent fungal problems.

Vegetative compatibility among these species has been demonstrated in the practice of avoiding the root suckering problem of $C$. glauca by grafting shoots of it onto $C$. equisetifolia (Ruehle, 1952) or C. cunninghamiana (Woodall and Geary, 1985).

\section{Hybridization}

Casuarina species are wind pollinated and can hybridize, resulting in the movement of genes between species (introgression) (Boland et al., 1996; El-Lakany, 1990; Ho et al., 2002; Moncur et al., 1997; Wilson and Johnson, 1989). With the advent of modern molecular biology tools, the occurrence of hybridization has been supported by DNA studies. Previously, observers had to rely on visual traits leading to only a few actual observations. Among the reports in the literature on this subject, those few observations have simply been repeated, leading to the largely unsubstantiated conclusion that hybrids occur routinely.

From an ecological perspective, C. equisetifolia is well equipped to propagate itself because it is monoecious and self-compatible; thus, individual plants are prolific seed producers. Furthermore, it is likely to produce hybrids when the other species are nearby. C. cunninghamiana and C. glauca are dioecious. Male and female plants of these species would need to be within wind-pollination range of each other to produce hybrid seeds. Studies of wild populations of these species in Australia indicate that hybrids may occur naturally along the interfaces of adjacent populations (Boland et al., 1996) and among introduced, mixed populations of these species (Ho et al., 2002).

In Florida, hybridization has long been suggested, leading to the speculation that hybrids have formed (Morton, 1980; Rockwood et al., 1990; Schardt and Schmitz, 1990; Woodall and Geary, 1985). Another consequence of this speculation has been the assumption that identification of the three species is difficult because of the presence of hybrids (Ho et al., 2002; Schardt and Schmitz, 1990).

One of the most useful Florida studies of Casuarina was conducted by two U.S.D.A. Forest Service scientists while located at the Southeastern Forest Experiment Station in Lehigh Acres (Woodall and Geary, 1985). Their document provides excellent descriptions of the species. They cite several publications indicating that occasional natural hybrids have been discovered between C. glauca and C. cunninghamiana in Australia and Egypt (which may not be likely in Florida because of the low plant numbers of the latter and the apparent absence of cones in the former). The authors also report their suspicions, based on plant morphology, that hybrids, particularly between C. glauca and C. equisetifolia, have occurred in Florida. They encountered some individual trees appearing to have certain characteristics inherited from the two probable parents. That suspicion was supported by identifications provided by an expert from the Royal Botanic Garden in Sydney, Australia. The authors state that C. cunninghamiana "is not a suspected parent of most putative hybrids because bark, cone or staminate spike features do not suggest it, but the existence of hybrids would not surprise us."

An issue related to observable characteristics (phenotype) among plants in a population is whether variability results from the mixing of species, e.g., through hybridization, or is normal variability within a species (El-Lakany, 1990; Moran et al., 1989; Yasodha, et al., 2004). DNA analyses have lent some understanding to this question. For example, C. equisetifolia, C. cunninghamiana, and C. glauca were brought to Taiwan over a century ago for use as pioneer plants in coastal forests. An initial study (Hwang and Hsiao, 1985) of morphological characters led to the conclusion that hybridization was likely among the three species and that C. glauca and C. cunninghamiana were closely related. In a 2002 study using a modern molecular tool called randomly amplified polymorphic DNA, or RAPDs, the authors concluded that (1) the genetic diversity among the plants in Taiwan was significantly higher than among plants in native provenances. They interpreted that result as support for interspecific hybridization; (2) gene movement occurred primarily between C. glauca and C. equisetifolia and less so with C. cunninghamiana; and, (3) backcrossing to C. equisetifolia is the source of most hybrids (Ho et al., 2002). Gaskin et al. (2009), using genetic techniques, identified Casaurina glauca, Casaurina cunninghamiana and Casaurina equisetifolia ssp. equisetifolia in Florida. They identified hybrid combinations of C. glauca and $C$. equisetifolia ssp. equiisetifolia, whereas eividence for hybrids of C. glauca and C. cunninhamiana was inconclusive and no evidence was found of hybrids between C. equisetifolia and C. cunninghamiana. 


\section{Ecological Traits, Environmental Assessment, and Regulation}

Various species of Casuarina were introduced into the United States in the late 1800s (Morton, 1980). The three species present in Florida were introduced between the turn of the century and perhaps the 1920s (Langeland and Burks, 1998). University of Florida and University of South Florida herbarium records show that samples were collected as early as 1900. Plants of C. equisetifolia, C. cunninghamiana, and C. glauca became established primarily along the southeastern and southwestern coasts. Since then they have spread to one extent or another to many parts of the state (Langeland and Burks, 1998; USDA-NRCS, undated). Distribution maps show the locations of the species in many areas of Florida, usually by county, but they can be misleading because they do not provide any indication of the size of the plant populations.

C. equisetifolia and C. glauca are rgulated by the Florida Department of Agriculture and Consumer Services (FDACS) as "Florida Noxious Weeds" (5B-57.007 FAC). It is unlawful "to introduce, multiply, possess, move, or release" a Florida Noxious Weed without a permint issued by FDACS (5B-57.004 FAC). C. equisetifolia and C. glauca, as well as C. cunninghamiana are also regulated by FDACS by inclusion of "Casuarina spp." as Class I Prohibited Aquatic Plants, which prohibits them from possession, collection, transportation, cultivation, and importation without a permit from the Department (5B-64.001 FAC). This listing was previously 62C-52.001 FAC in rules of the Florida Department of Environmental Protection but responsibility was transferred to FDACS. The Florida Exotic Pest Plant Council (FLEPPC) lists C. cunninghamiana with Category II invasive species, which are defined as "Invasive exotics that have increased in abundance or frequency but have not yet altered Florida plant communities to the extent shown by Category I species." The FLEPPC list has no statutory authority. These species may also be regulated by local ordinances.

The three species of Casuarina have proven to be well suited to many environments in Florida. They were originally considered useful, e.g., as an ornamental plant or for windbreaks. As late as 1985, there were studies of their agroforestry potential (Woodall and Geary, 1985). However, C. equisetifolia and C. glauca in particular have grown aggressively to the point of invading and interfering with natural plant communities in some areas. Dr. Julia Morton was among the first to recognize the environmental impact of Casuarina and published a warning (Morton, 1980).
Casuarina equisetifolia has the widest distribution worldwide of the three species. It is considered to be a naturalized exotic plant in Florida where it now sustains itself without cultivation. It is highly invasive, salt tolerant, relatively cold intolerant (thus, limiting its range to primarily south Florida coastal environments), and a prolific seed producer, which explains its problematic virtual invasion of areas of the Everglades. In a stewardship report by The Nature Conservancy, C. equisetifolia problems in Everglades National Park were cited, and it was concluded that it was no longer financially feasible to manage this species in the park (Elfers, 1988).

The invasive/suppressive potential of C. equisetifolia was evident in the response of a coastal ecosystem after its removal (Digiamberardino, 1986). The study was conducted on Jupiter Island (Martin County) and terminated after 6 months. Once the Casuarinas were removed, there was an immediate regrowth by native plants. In another study, 5,300 seedlings of 37 native species were planted under established C. equisetifolia trees on spoil islands in the Indian River (Fernald and Doren, 1991). The preliminary results indicated that the $C$. equisetifolia "provide a valuable nurse crop ."

C. glauca is easily spotted in small to large groups of plants throughout south and central Florida. In its native areas, this species is usually found along saline waterways and near the coast. It is salt tolerant, but not to the same degree as C. equisetifolia. C. glauca is purported to have been introduced to complement $C$. equisetifolia, but it proved to be less salt tolerant and did not become established on Florida beaches. The principal concern with this species, given that it may not produce seeds consistently or at all in Florida, is its invasiveness due to root suckering. That trait is apparent wherever the species is found in Florida. Communities of C. glauca are noticeably devoid of other vegetation.

C. cunninghamiana is typically the dominant plant in riverine habitats, where it occurs naturally in the southern hemisphere, often upstream from C. glauca in freshwater locations along streams and rivers (AgroForestryTree Database). It is the largest of the Casuarina species in Australia. This species, while it grows well in a range of sandy and gravelly soils and pHs and tolerates wet conditions and freezes, is less tolerant of saline conditions than C. equisetifolia and is about equal in that regard to C. glauca (Morris and Collopy, 1999; Sun and Dickinson, 1995).

The monitoring and eradication of these species have continued with periodic environmental assessments leading to the formation of task forces (Elfers, 1988; Ferriter, 
et al., 2002; Gann et al., 2001-2007). For example, the Florida Keys Invasive Exotics Task Force in 2005 rated $C$. equisetifolia as "highly invasive in wetlands and uplands" with wind-blown seed dispersal all year (Hadden et al., 2005). Their placement of this species in Category I means that it is "altering Florida Keys native plant communities by displacing native species." The other two species are in Category II meaning "not yet altered Florida Keys plant communities." They are described as "C. cunninghamiana suckering, somewhat cold tolerant, very limited in the Keys; wind-blown seeds year round; C. glauca - less salt tolerant than C. equisetifolia and less widespread; no seeds, suckers off planted trees."

As of 1990 Casuarina species had not been surveyed in Florida as mentioned in a FDEP Annual Report (Schardt and Schmitz, 1990). In that report, it is further stated that "There is extensive hybridization of these species making identification difficult." Also, "it is very abundant in southern Florida and extends as far north as Gainesville," and "Removal efforts have been on-going in state parks since 1975."

Two of the species in Florida have also been subjected to Pacific Island Ecosystems at Risk assessments (PIER, undated). They are among the most comprehensive assessments using a point scoring approach. C. equisetifolia outscored C. cunninghamiana 15 to 12 (lower scores are better) indicating the more serious concern with the environmental impact of the former species.

\section{Current assessment of C. cunninghamiana in Florida.}

Trees of this species have been part of the Florida invasive species eradication and management program. However, there is little published evidence indicating the existence of large populations or its widespread distribution in Florida during the decades after its introduction, or today. The general absence of any mention of this species in available literature (e.g., Langeland and Burks, 1998) in combination with its environmental impact classifications suggests a low level of concern as compared to the other species. Gann et al. (2001-2007) report C. cunninghamiana from only four natural areas and six counties of southern Florida, and only from "upland disturbed habitats." Herbarium records exist for only eight counties (Wunderlin and Hansen, 2004). EddMaps (http://www.eddmaps.org/florida/distribution/ viewmap.cfm?sub=5230) reports this species in four locations in two additional counties. There are no reports or assessments that hybrids of greater ecological concern than the parents have developed in Florida or elsewhere (Gaskin et al. 2009; Boland, et al., 1996; El-Lakany, 1990; Merwin et al., 1995; Woodall and Geary, 1985).

\section{Use of Casuarina Species}

Three international Casuarina workshops and many other meetings testify to the world significance of these plants especially C. equisetifolia (El-Lakany et al., 1990; Midgley et al., 1983; Pinyopusarerk et al., 1996). The species of Casuarina described in this review have been used in countries as diverse as Egypt, Peru, India, Indonesia, and Vietnam and many other places as windbreaks, ornamentals, fuelwood, timber, poles, pulpwood, pioneer plants for reforestation, and for erosion management (AgroForestryTree Database; Boland et al., 1996; Das, 1996; El-Lakany, 1996; Montes, 1996; Whistler and Elevitch, 2006). Field trials with C. cunninghamiana have been conducted in California to search for provenance differences leading to more frost-tolerant plants for use in windbreaks (Merwin et al., 1995).

Florida researchers have also studied possible commercial uses of Casuarina and concluded that because of its fast growth, coppicing abilities, and wood properties, the plants are suitable for use in pulpwood and biomass production (Comer et al., 1986; Rockwood et al., 1983). The three species differed in cold tolerance, growth, and possibly competitive ability in a planting at Belle Glade; C. equisetifolia was very freeze sensitive and C. cunninghamiana slightly less so, while C. glauca survived and grew well at a high stand density, reaching a height over $8 \mathrm{~m}$ in 82 months (Rockwood and Geary, 1991).

Windbreaks are an established means of protecting agricultural crops (Peri and Bloomberg, 2002; Sun and Dickinson, 1997) by helping to prevent erosion and providing more pleasant human environments. When native or introduced Casuarinas are employed for the latter purpose, it was often in coastal and other suitable environments. Certain characteristics such as rapid growth, attractive appearance, ease of propagation and establishment, and life-long retention of foliage from the base to the top of the plant favored their use as a windbreak and, in some instances, ornamental uses for the same purpose (El-Lakany, 1996). In some locales such as Florida, the usefulness of Casuarinas as windbreaks is challenged by severe wind events like hurricanes (Burch, 2003). The relatively shallow root systems of these plants (El-Lakany and Mohamed, 1993, 1993a) have not provided adequate anchorage in such storms to prevent wind-throw; also, limb breakage occurs. In a recent post-2004 Florida hurricane assessment, $58.5 \%$ of C. equisetifolia trees on Sanibel Island off the west coast were broken off or uprooted (Burch, 2006). Live oak and Casuarina trees had comparable limb damage, but more trees of the latter species were wind-thrown. At inland and coastal locations where Casuarina trees were located near citrus groves and 
subjected to hurricane force winds in 2004 and 2005, but of lower velocity, damage was minimal or absent (WSC, personal observation). There are similar risks for any windbreak tree, however, since growing to great heights also increases the tendency to blow over when subjected to hurricane-force winds.

Windbreaks are also valuable for protecting citrus and other orchard crops. For living windbreaks, the best plant species are those that are suitable for a broad range of soil and environmental conditions, that reach functional size quickly and perform effectively with little to no maintenance, that are readily available and inexpensive, that establish easily and that do not complete with the citrus trees (El-Lakany and Mohamed, 1993). In Florida, of particular concern are plant species that can be used across our broad range of soils, that are cold tolerant, windfirm, and fast-growing, and that can be planted alone in single rows. The latter two traits are especially essential because (1) canker disease is present throughout the state. Canker bacteria spread primarily in wind-driven rain. Any means to manage the wind (windbreaks) contributes significantly to canker control; and (2) many citrus groves are located in the poorly-drained coastal areas often referred to as the flatwoods. Such sites are prepared with external and internal waterways for drainage. Little land is available for other than drainage requirements, roads, and the citrus trees. Thus, space is limited for windbreak trees.

In virtually all citrus industries worldwide where windbreaks are employed routinely, various plant species have been evaluated and the conclusion reached that $C$. cunninghamiana is the best performer overall. Windbreaks are also recommended in Florida. The suggested windbreak plants and illustrations of local and international uses are given on the UF/CREC website, http://www.crec.ifas.ufl. edu/extension/windbreaks, along with plant species eligible for cost-share through the Environmental Quality Incentive Program of the USDA-Natural Resources Conservation Service. C. cunninghamiana is not included among the suggested plant species because it is prohibited, but its overall characteristics surpass those of all the currently recommended plants. That conclusion was also reported in 1937 for citrus in Florida (Newins, 1937).

The Casuarina cunninghamina Windbreak Pilot Program was implemented in 2008 (581.091 FS). This legislation provides for obtaining a permit from FDACS to plant this species as a windbreak for a commercial citrus grove with certain provisions. FDACS monitors permitted sites and issues annual reports of inspecitions.

\section{Literature Cited}

AgroforestryTree Database. Undated. Casuarina cunninghamiana. World Agroforestry Center. http://www. worldagroforestrycentre.org/sea/Products/AFDbases/AF/ asp/SpeciesInfo.asp?SpID $=476$

AgroforestryTree Database. Undated. Casuarina equisetifolia. World Agroforestry Center. http://www. worldagroforestrycentre.org/sea/Products/AFDbases/AF/ asp/SpeciesInfo.asp?SpID $=477$

AgroforestryTree Database. Undated. Casuarina glauca. World Agroforestry Center. http://www.worldagroforestrycentre.org/sea/Products/AFDbases/AF/asp/SpeciesInfo. asp? SpID $=479$

Atlas of Florida Vascular Plants website. University of South Florida. http://www.plantatlas.usf.edu/

Boland, D.J., M.W. Moncur, and K. Pinyopusarerk. 1996. Review of some floral and vegetative aspects to consider when domesticating Casuarina. Proc. Third Int. Casuarina Workshop, p.17-25. CSIRO, Australia.

Burch, D. 2003. How to minimize wind damage in the South Florida garden. Univ. Fla. Coop. Ext. Serv. Publ. ENH-64.

Burch, J.N. 2006. Hurricane winds, tropical storm winds, and tree fragmentation, p. 277-282. In: D. Harmon, ed., People, places, parks: proceedings of the 2005 George Wright Society conference on parks, protected areas, and cultural sites. Hancock, MI, the G.W. Society.

Comer, C.W., L.F. Conde, D.L. Rockwood, and T.F. Geary.1986.Casuarina cultural improvement in Florida. Nitrogen Fixing Trees Research Report 4: 53

Das, B.L. 1996. Role of Casuarina in stabilization of shifting sand in India and its impact on integrated rural development. Proc. 2nd Int. Casuarina Workshop, p.204-208. SIRO, Australia.

Digiamberardino, T. 1986. Changes in a southeast Florida coastal ecosystem after elimination of Casuarina equisetifolia. Nova University, Davie, FL Thesis.

Duhoux, E., C. Franche, D. Bogusz, D. Diouf, V.Q. Le, H. Gherbi, B. Sougoufara, C. LeRoux and Y. Dommergues. 1996. Biotech. in Agric. and Forestry 25:76-94. 
Elfers, S. 1988. Element stewardship abstract for Casuarina equisetifolia. The Nature Conservancy, Arlington, VA.

El-Lakany, M. 1990. Provenance trials of Casuarina glauca and C. cunninghamiana in Egypt. Proc. 2nd Int. Casuarina Workshop, p. 12-22. CSIRO, Australia.

El-Lakany, M. 1996. A brief account of Casuarina research: past achievements and future trends. Proc. 3rd Int. Casuarina Workshop, p.12-16. CSIRO, Australia.

El-Lakany, M. and S.Y. Mohamed. 1993. Root characteristics of four tree species as affected by irrigation systems. Alex. J.Agri. res. 38(1):183-210.

El-Lakany, M. and S.Y. Mohamed. 1993a. Effects of species composition on the root characteristics of young Acacia saligna, Casuarina cunninghamiana and Eucalyptus camaldulensis trees. Alex. J.Agri. res. 38(1):211-227.

El-Lakany, M., J.W. Turnbull, J.L. Brewbaker (eds.). 1990. Advances in Casuarina research and utilization. Proc. 2nd Int. Casuarina Workshop. CSIRO, Australia.

El-Lakany, M.h., T.A. Omran and M.S. Shehata. 1989. Variation in seed characteristics of Casuarina as affected by species, season of collection and position on tree crown. The International tree Crops J. 5:237-245.

Fernald, R.F. and R.F. Doren. 1991. Establishment of native hammock vegetation on spoil islands dominated by Australian pine (Casuarina equisetifolia) and Brazilian pepper (Schinus terebinthifolius), p.131-145. In: TD Center, RF Doren, RL Hofstetter, RL Myers, and LD Whitaker (eds.). Proc. of the Symposium on exotic pest plants. Tech, Rpt. NPS/NREVER/NRTR-91/06, Univ. Miami.

Ferriter, A, K. Serbesoff-King, M. Bodle, C. Goodyear, B. Doren, and K. Langeland. 2002. Comprehensive review of exotic species in the EPA. South Florida Water Mgt. District 2002 Everglades Consolidated Report. Chapter 8E, p. $8 \mathrm{E} 1-8 \mathrm{E} 36$.

Florida Dept. Environmental Protection, Bureau of Invasive Plant Management. Undated. Weed alert, Australian pine. http://www.myfwc.com/WILDLIFEHABITATS/InvasivePlants_index.htm

Floridata. Undated. Casuarina equisetifolia. http://www. floridata.com/ref/c/casu_equ.cfm
Gann, G.D., K.A. Bradley, and S.W. Woodmansee. 20012007. The floristic inventory of South Florida database online. Casuarina cunninghamiana Miq. Beefwood, River sheoak. The Institute for Regional Conservation, Miami. http://www.regionalconservation.org/ircs/database/plants/ PlantPage.asp?TXCODE=Casucunn

Gaskin, J. F. G. S. Wheeler, M. F. Purcell, and G. S. Taylor. Molecular evidence of hybridization in Florida's sheoak (Casaurina spp.) invasion. 2009. Molecular Ecology 18: 3216-3226.

Goh, C.J., P. Lakshmanan, C.L. Lee, C.S. Loh and M. Tanaka. 1995. A simple and efficient method for clonal propagation of Casuarina sumatrana (de Vrise) L. Johnson. Plant Growth Regulation 17:115-120.

Hadden, K., K. Frank, and C. Byrd. 2005. Identification guide for invasive exotic plants of the Florida Keys. Fla. Keys Invasive Exotics Task Force. http://www.keysgreenthumb.net/exotics_list.pdf

Ho, K.Y., J.C. Yang, and J.Y. Hsiao. 2002. An assessment of genetic diversity and documentation of hybridization of Casaurina grown in Taiwan using RAPD markers. Int. J. Plant. Sci. 163(5):831-836.

Hwang, Y.H. and J.Y. Hsiao. 1985. A taxonomic study on Casuarinaceae in Taiwan. Proc. Natl. Sci. Council Rep. China Part B 9:13-19.

Karoshi, V.R., G.V. Hegde and S.M. Hiremath. 2000. Macropropagation of Casuarina cunninghamiana Miq. via mistless tunnel. J. Trop. Forestry 16:79-81.

Kha, L.D. 1996. Variation characteristics and propagation ability of Casuarina equisetifolia by cuttings in Vietnam. Proc. 2nd Int. Casuarina Workshop, p. 103. CSIRO, Australia.

Lal, P, H.D. Kulkarni, and K. Srinivas. 1996. Clonal planting stock of Casuarina: ITC Bhadrachalam experience. Proc. 2nd Int. Casuarina Workshop, p. 162-166. CSIRO, Australia.

Langeland, K. A. and K. Craddock Burks (eds.).1998.Identification \& biology of non-native plants in Floridas natural areas.University of Florida, Gainesville.165 pp.(Available at: http://www.fleppc.org/ID_book.htm) 
Lundquist, R., and J.G. Torrey. 1984. The propagation of Casuarina species from rooted cuttings. Bot. Gaz. 145(3):378-384.

Merwin, M.L., J.A. Martin, and R.D. Westfall. 1995. Provenance and progeny variation in growth and frost tolerance of Casuarina cunninghamiana in California, USA. Forest Ecol. Mgt. 79(3):161-171.

Midgley, S.J., J.W. Turnbull, and R.D. Johnston (eds.). 1983. Casuarina ecology, management, and utilization. Proc. $1^{\text {st }}$ Int. Casuarina Workshop. CSIRO, Australia.

Moncur, M.W., D.J. Boland and J.L. Harbard. 1997. Aspects of the floral biology of Allocasuarina verticillata (Casuarinaceae). Aust. J. Botany 45:857-869.

Montes G. L. 1996. Study of the adaptation of the genus Casuarina in the Rimac Rivery, Peru. Proc. 2nd Int. Casuarina Workshop, p.41-43. CSIRO, Australia.

Moran, G.F., J.C. Bell, and J.W. Turnbull. 1989. A cline in genetic diversity in River she-oak Casuarina cunninghamiana. Aust. J. bot. 37:169-180.

Morris, J.D. and J.J. Collopy. 1999. Water use and salt accumulation by Eucalyptus camaldulensis and Casuarina cunninghamiana on a site with shallow saline groundwater. Agric. Water Mgt. 39:205-227.

Morton, J.F. 1980. The Australian pine or Beefwood (Casuarina equisetifolia L.), an invasive weed tree in Florida. Proc. Fla. State Hort. Soc. 93:87-95.

Newins, H.S. 1937. Windbreaks for prevention of damage to citrus trees. Proc. Fla. State Hort. Soc. 38:43-46.

Olson, D.F. Jr., E.Q.P. Petteys, and J.A. Parrotta. Undated. Casuarina Rumph. ex L. http://www.nsl.fs.fed.us/C\%20 genera\%201.pdf. Page 32.

Pacific Island Ecosystems at Risk (PIER). Undated. Casuarina cunninghamiana. http://www.hear.org/pier/wra/ pacific/casuarina_cunninghamiana_htmlwra.htm

Pacific Island Ecosystems at Risk (PIER). Undated. Casuarina equisetifolia. http://www.hear.org/pier/species/ casuarina_equisetifolia.htm

Parthiban, K.T., C. Surendran, R. Narayanan, C.T. Wheeler, and V.K. Ravichandran. 1996. Micropropagation of Casuarina equisetifolia. Proc. 2nd Int. Casuarina Workshop, p.104-108. CSIRO, Australia.
Peri, P.L. and M. Bloomberg. 2002. Windbreaks in southern Patagonia, Argentina: A review of research on growth models, windspeed reduction, and effects on crops. Agroforestry Systems 56:129-144.

Pinyopusarerk, K., J.W. Turnbull, and S.J. Midgley (eds.). 1996. Recent Casuarina research and development. Proc. Third Int. Casuarina Workshop. CSIRO, Australia.

Rockwood, D.L. and T.F. Geary. 1991. Chapter 20: Growth of 19 exotic and two native tree species on organic soils in southern Florida. In: Proc. Symposium on Exotic Pest Plants, November 2-4, 1988, Miami, FL. USDI Nat. Park Serv. Rpt. NPS/NREVER/NRTR-91/06. p. 283-302.

Rockwood, D.L., J.B. Huffman, and L.F. 1983. Conde. Potential of Casuarina spp. for biomass production in Florida.1980 IUFRO Fast Growing Trees Symp.Silvicultura 8(30): 376

Rockwood, D.L., R.F. Fisher, L.F. Conde, and J.B. Huffman. Casuarina. In: Silvics of North America. Volume 2, Hardwoods.Agriculture Handbook 654.p. 240-243. http://www. na.fs.fed.us/spfo/pubs/silvics_manual/volume_2/casuarina/ casaurina.htm

Ruehle, G.D. 1952. Grafted Casuarina trees for use as windbreaks or ornamentals. Proc. Fla. State Hort. Soc 65:199-201.

Schardt, J.D. and D.C. Schmitz. 1990. 1990 Florida aquatic plant survey. Fla. Dept. Nat. Res., Bureau Aquatic Plt. Mgt. Tech. Rpt. 91-CGA.

Sivakumar, V., R. Anandalakshmi, R.R. Warrier, B.G. Singh, M. Tigabu and P.C. Odén, 2007. Petroleum flotation technique upgrades the germinability of Casuarina equisetifolia seed lots. New Forests 24:281-291.

Sun, D. and G.R. Dickinson. 1995. Salinity effects on tree growth, root distribution and transpiration of Casuarina cunninghamiana and Eucalyptus camaldulensis. Forest Ecol. Mgt. 77:127-138.

Sun, D. and G.R. Dickinson. 1997. Early growth of six native Australian tree species in windbreaks and their effects on potato growth in tropical northern Australia. Forest Ecol. Mgt. 95:21-34.

University of Florida Herbarium website. http://www. flmnh.ufl.edu/herbarium/cat/ 
USDA-NRCS. Undated. Plants profile, countydistribution: Casuarina cunninghamiana Miq.-river sheoak in the State of Florida. http://plants.usda.gov/java/county?state_name= Florida\&statefips $=12 \&$ symbol=CACU8

Whistler, W.A. and C.R. Elevitch. 2006. Casuarina equisetifolia (beach she-oak) C. cunninghamiana (river she-oak). Species profiles for Pacific Island agroforestry. http://www. agroforestry.net/tti/Casuarina-she-oak.pdf

Wilson, K.L. and L.A.S. Johnson. 1989. Casuarinaceae. In: A.S. George (ed.) Flora of Australia, vol. 3. Hamamelidales to Casuarinales. Aus. Govt Printing Serv., Canberra.

Woodall, S.L. and T.F. Geary. 1985. Identity of Florida Casuarinas. USDA Forest Serv. SE Forest Expt. Stn. Res. Note SE-332.

Wunderlin, R. P., and B. F. Hansen. 2008. Atlas of Florida Vascular Plants http://www.plantatlas.usf.edu/. [S. M. Landry and K. N. Campbell (application development), Florida Center for Community Design and Research.] Institute for Systematic Botany, University of South Florida, Tampa.

Yasodha, R., M. Kathirvel, R. Sumathi, K. Gurumurthi, S. Archak, and J. Nagaraju. 2004. Genetic analyses of Casuarinas using ISSR and FISSR markers. Genetica 122:161-172. 